\title{
Analysis of the evolution of those operated on with minimal access surgery in our hospital. Does it present better results than the conventional one?
}

\section{Análisis de la evolución de los operados mediante cirugía de mínimo acceso en nuestro hospital. ¿Presenta mejores resultados que la convencional?}

Nora García*, Aníbal Bermúdez, Ma. Ángeles Martín, Carmen Carmona, Cristina Jaén, and

Tomás Daroca

Department of Cardiovascular Surgery, Hospital Puerta del Mar, Cádiz, Spain

\begin{abstract}
Symptomatic severe aortic stenosis is the most prevalent surgical pathology in cardiac surgery, and its isolated replacement has historically been performed by means of complete middle sternotomy. However, a great revolution has recently taken place, especially after the arrival of sutureless aortic prostheses that, together with a new impulse by cardiac surgery towards a less invasive course, has caused the replacement of said valve to be carried out more and more frequently due to these prostheses and minor access incisions. For this reason, we carried out a review of the cases operated on in our service from the beginning of the minimum access surgery program, comparing them with the results of the cases operated at the same time using conventional surgery.
\end{abstract}

Key words: Surgery. Minimal access. Conventional. Comparison. Results.

\section{Resumen}

La estenosis aórtica severa sintomática es la patología quirúrgica más prevalente en cirugía cardiaca y su sustitución aislada se ha realizado históricamente mediante esternotomía media completa. Sin embargo, se ha producido recientemente una gran revolución, especialmente tras la llegada de las prótesis aórticas sin suturas que, unido a un nuevo impulso por la cirugía cardiaca hacia un rumbo menos invasivo, ha provocado que el reemplazo de dicha válvula se lleve a cabo cada vez más frecuentemente por dichas prótesis y por incisiones de mínimo acceso. Por ello, realizamos una revisión de los casos intervenidos en nuestro servicio desde el inicio del programa de cirugía de mínimo acceso comparándolos con los resultados de los casos intervenidos en la misma época mediante cirugía convencional.

Palabras claves: Cirugía. Mínimo acceso. Convencional. Comparación. Resultados.

Correspondence:

*Nora García

E-mail: noragb89@gmail.com DOragb89@gmail.com 10.24875/ACME.M21000223

Available online: $20-10-2021$ Arch Cardiol Mex (Eng). 2021;91(3):288-293 www.archivoscardiologia.com
article under the CC BY-NC-ND license (http://creativecommons.org/licenses/by-nc-nd/4.0/). 


\section{Introduction}

Aortic stenosis constitutes the valvular pathology that more frequently has a surgical indication and, historically, the procedure is performed by conventional sternotomy. However, since the beginning of cardiac surgery, interest arose on using less invasive routes, although it did not gain great acceptance. However, in recent years, cardiac surgery has undergone the resurgence and globalization of minimal access surgery, due to:

- The growth of interventional hemodynamics with percutaneous treatment of several pathologies, especially in the aortic valve, which has caused for cardiac surgery to be forced to get updated in order to be able to compete with it.

- Standardization of the steps in minimally invasive surgery with an approach mostly in the aortic valve that is mini-J sternotomy, with the publication of the results obtained at each center, demonstrating that it is a real alternative ${ }^{1}$.

- The arrival of sutureless aortic prostheses, which allow shortening the time required for implantation of said prosthesis and total cardiac ischemic time.

- Aging and increased comorbidity of patients who are referred to surgery, which is why being as less surgically aggressive as possible is tried.

On the other hand, in the literature, minimal access surgery has numerous advantages in patient evolution, such as: less need for mechanical ventilation and lower occurrence of respiratory complications, as well as shorter stay at the intensive care unit (ICU) and shorter hospital length of stay. Therefore, in an attempt to implement a minimal-access surgery program, performing isolated aortic valve replacement was started using a mini J-sternotomy procedure via the $3^{\text {rd }}-4^{\text {th }}$ intercostal space, given that it was the most widely used incision according to the literature and because it is the approach that more closely resembles full sternotomy, in addition to more easily allowing the reconversion to conventional technique to be carried out, among other advantages. With the purpose to analyze the results of this technique in our setting and to find out whether or not they are comparable to the results in other centers, we carried out this retrospective study, which compares the evolution of patients undergoing aortic valve replacement divided in two large groups: the mini-sternotomy group and that of full sternotomy ${ }^{1,2}$.

\section{Methods}

A retrospective, analytical, observational study was carried out to evaluate a non-deliberate intervention, since for their analysis, patients have been divided in two groups: group 1, which refers to aortic valve replacement with a Perceval ${ }^{\circledR}$ prosthesis by mini J-sternotomy, and group 2, which involves valve replacement by biological prostheses supported by conventional sternotomy, at the Cardiovascular Surgery Department of the Puerta del Mar Hospital between January 2016 and December 2019, with a total of 57 patients in each group.

As for statistical analysis, all obtained data were captured and processed on an anonymized and encrypted Excel ${ }^{\circledR}$ database. Data were then exported to a Statgraphics $^{\circledR}$ data file and, subsequently, the obtained data were analyzed using statistical programs and applications (SPSS ${ }^{\circledR}$ and R), with an analysis of variance being performed in order to find out whether there were statistically significant differences between both groups. The variables are shown in table 1.

\section{Results}

Regarding the sociodemographic variables, the sex variable was statistically significant, with a higher percentage of the women category in the mini-sternotomy group. As for comorbidity variables, a higher proportion of subjects with hypertension, dyslipidemia, chronic obstructive pulmonary disease (COPD) and diabetes were obtained in the mini-sternotomy group. The only proportion that was higher in group 2 was that of smokers, without any of the above differences being statistically significant.

On the other hand, in the case of complementary variables, ICU stay and hospital stay were longer in the mini-sternotomy group, with a mean of 5.65 days vs. 3.58 (U: 1,$139 ; p=0.004)$, and a mean of 15.67 days vs. 13.04 (U: $1,201.5 ; p=0.016$ ), i.e., statistically significant. In addition, a higher proportion of re-operated patients for bleeding within the first 24 hours, re-operated for other causes and development of mediastinitis were observed in the mini-sternotomy vs. sternotomy group, and after calculation with the chi-square test, of the latter, only reoperation for bleeding and reoperation for other causes were statistically significant $(p=0.052$ and $p=0.018$, respectively), as shown in table 2 .

Finally, with regard to the study main variables, i.e., respiratory complications and intubation time, the proportion of patients in the sternotomy group who had no respiratory complications was found to be higher, $80.7 \%$ vs. $68.9 \%$ for the mini-sternotomy group. The proportion of patients in the sternotomy group who remained intubated for less than 24 hours was also 
Table 1. Study variables

\begin{tabular}{|c|c|c|c|}
\hline Sociodemographic variables & $\begin{array}{l}\text { Type of } \\
\text { variable }\end{array}$ & Statistical nature & Category \\
\hline Age & Independent & Quantitative, measured in years & \\
\hline Sex & Independent & Dichotomous quantitative & $\begin{array}{l}\text { - Man } \\
\text { - Woman }\end{array}$ \\
\hline $\begin{array}{l}\text { Comorbidity variables } \\
\text { Smoking } \\
\text { Body surface area } \\
\text { Hypertension } \\
\text { Diabetes mellitus } \\
\text { Dyslipidemia } \\
\text { COPD }\end{array}$ & $\begin{array}{l}\text { Independent } \\
\text { Independent } \\
\text { Independent } \\
\text { Independent } \\
\text { Independent } \\
\text { Independent }\end{array}$ & $\begin{array}{l}\text { Dichotomous qualitative } \\
\text { Quantitative, measured in } \mathrm{m}^{2} \\
\text { Dichotomous qualitative } \\
\text { Dichotomous qualitative } \\
\text { Dichotomous qualitative } \\
\text { Dichotomous qualitative }\end{array}$ & $\begin{array}{l}\text { - Yes } \\
\text { - No } \\
\text { - Yes } \\
\text { - No } \\
\text { - Yes } \\
\text { - No } \\
\text { - Yes } \\
\text { - No } \\
\text { - Yes } \\
\text { - No }\end{array}$ \\
\hline $\begin{array}{l}\text { Complementary variables } \\
\text { Left ventricular ejection fraction } \\
\text { NYHA functional class } \\
\text { Cardiac ischemic time } \\
\text { Intensive care unit stay } \\
\text { Total hospital stay } \\
\text { Postoperative mortality ( } 30 \text { days) } \\
\text { Heart rate } \\
\text { Mediastinitis } \\
\text { Bleeding within first } 24 \mathrm{~h} \\
\text { Need for urgent re-intervention for bleeding } \\
\text { Need for urgent re-intervention for other causes } \\
\text { Type of valve lesion }\end{array}$ & $\begin{array}{l}\text { Independent } \\
\text { Independent } \\
\text { Independent } \\
\text { Independent } \\
\text { Independent } \\
\text { Independent } \\
\text { Independent } \\
\text { Independent } \\
\text { Independent } \\
\text { Independent } \\
\text { Independent } \\
\text { Independent }\end{array}$ & $\begin{array}{l}\text { Dichotomous qualitative } \\
\text { Ordinal qualitative } \\
\text { Quantitative, measured in minutes } \\
\text { Quantitative, measured in days } \\
\text { Quantitative, measured in days } \\
\text { Dichotomous quantitative } \\
\text { Polychotomous qualitative } \\
\text { Dichotomous qualitative } \\
\text { Quantitative, measured in milliliters } \\
\text { Dichotomous qualitative } \\
\text { Dichotomous qualitative } \\
\text { Polychotomous qualitative }\end{array}$ & $\begin{array}{l}\text { - Yes } \\
\text { - No } \\
\text { - Sinus rhythm } \\
\text { - Atrial fibrillation } \\
\text { - Pacemaker } \\
\text { - Yes } \\
\text { - No } \\
\text { - Yes } \\
\text { - No } \\
\text { - Yes } \\
\text { - No } \\
\text { - Stenosis } \\
\text { - Regurgitation } \\
\text { - Both }\end{array}$ \\
\hline $\begin{array}{l}\text { Study variables } \\
\text { Intubation time } \\
\text { Respiratory complications }\end{array}$ & $\begin{array}{l}\text { Dependent } \\
\text { Dependent }\end{array}$ & $\begin{array}{l}\text { Qualitative dichotomous } \\
\text { Qualitative polychotomous }\end{array}$ & $\begin{array}{l}\text { - More than } 24 \mathrm{~h} \\
\text { - Less than } 24 \mathrm{~h} \\
\text { - No complications } \\
\text { - Pleural effusion } \\
\text { - Atelectasis } \\
\text { - Pneumonia } \\
\text { - Respiratory failure } \\
\text { - Respiratory distress }\end{array}$ \\
\hline
\end{tabular}

COPD: Chronic obstructive pulmonary disease; NYHA: New York Heart Association.

higher. However, when the chi-square test was applied with regard to each group, no statistically significant differences were obtained. Furthermore, the mortality variable was higher, although only slightly and with no significance, in the sternotomy group, specifically
$5.3 \%$ vs. $1.8 \%$, which reflects that despite having more admissions to the ICU and hospital and a higher incidence of respiratory events, the mini-sternotomy group evolved more favorably than the sternotomy group, as reflected on Table 2. 
Table 2. Bivariate analysis

\begin{tabular}{|c|c|c|c|}
\hline Complementary variables & $\begin{array}{l}\text { Mini-sternotomy } \\
\quad(\mathrm{n}=57)\end{array}$ & Sternotomy (n = 57) & $\mathrm{p}(\mathrm{p}<0.05)$ \\
\hline Aortic clamping time & $60.44(56.07-65.80)$ & $64(58.42-69.58)$ & 0.293 \\
\hline Bleeding from drains $24 \mathrm{~h}$ & $247.02(202.27-291.76)$ & $285.79(235.23-336.35)$ & 0.357 \\
\hline Intensive care unit stay & $5.65(4.16-7.14)$ & $3.58(2.52-4.64)$ & 0.004 \\
\hline Total hospital stay & $15.67(13.27-18.07)$ & $13.04(11.20-14.87)$ & 0.016 \\
\hline Mortality & $1(1.8 \%)$ & $3(5.3 \%)$ & 0.309 \\
\hline Reoperation for bleeding & $11(19.3 \%)$ & $4(7 \%)$ & 0.052 \\
\hline Reoperation for other causes & $13(22.8 \%)$ & $4(7 \%)$ & 0.018 \\
\hline Mediastinitis & $2(3.5 \%)$ & $0(0 \%)$ & 0.154 \\
\hline $\begin{array}{l}\text { NYHA } \\
\text { I } \\
\text { II } \\
\text { III } \\
\text { IV }\end{array}$ & $\begin{array}{c}0(0 \%) \\
32(56.1 \%) \\
25(43.9 \%) \\
0(0 \%)\end{array}$ & $\begin{array}{c}1(1.8 \%) \\
33(57.9 \%) \\
22(38.6 \%) \\
1(1.8 \%)\end{array}$ & 0.531 \\
\hline $\begin{array}{l}\text { Left ventricular ejection fraction } \\
\text { Preserved } \\
\text { Decreased }\end{array}$ & $\begin{array}{c}51(89.5 \%) \\
6(10.5 \%)\end{array}$ & $\begin{array}{c}57(100 \%) \\
0(0 \%)\end{array}$ & 0.012 \\
\hline $\begin{array}{l}\text { Heart rate } \\
\text { Sinus rhythm } \\
\text { AF } \\
\text { Pacemaker }\end{array}$ & $\begin{array}{c}52(91.2 \%) \\
4(7 \%) \\
1(1.8 \%)\end{array}$ & $\begin{array}{c}47(82.5 \%) \\
7(12.3 \%) \\
3(5.3 \%)\end{array}$ & 0.355 \\
\hline $\begin{array}{l}\text { Type of valve lesion } \\
\text { Stenosis } \\
\text { Regurgitation } \\
\text { Mixed }\end{array}$ & $\begin{array}{c}45(78.9 \%) \\
2(3.5 \%) \\
10(17.5 \%)\end{array}$ & $\begin{array}{c}43(75.4 \%) \\
1(1.8 \%) \\
13(22.8 \%)\end{array}$ & 0.680 \\
\hline Study variables & $\begin{array}{l}\text { Mini-sternotomy } \\
\quad(n=57)\end{array}$ & Sternotomy ( $\mathrm{n}=57$ ) & $p(p<0.05)$ \\
\hline $\begin{array}{l}\text { Intubation time } \\
\quad<24 \mathrm{~h} \\
>24 \mathrm{~h}\end{array}$ & $\begin{array}{c}48(84.2 \%) \\
9(15.8 \%)\end{array}$ & $\begin{array}{l}51(89.5 \%) \\
6(10.5 \%)\end{array}$ & 0.406 \\
\hline $\begin{array}{l}\text { Respiratory complications } \\
\text { No complications } \\
\text { Pleural effusion } \\
\text { Pneumonia } \\
\text { Resp. failure } \\
\text { Atelectasis } \\
\text { Distress } \\
\text { Pneumonia }\end{array}$ & $\begin{array}{c}39(68.9 \%) \\
8(14 \%) \\
5(8.8 \%) \\
0(0 \%) \\
4(7 \%) \\
1(1.8 \%) \\
5(8.8 \%)\end{array}$ & $\begin{array}{c}46(80.7 \%) \\
7(12.3 \%) \\
1(1.8 \%) \\
1(1.8 \%) \\
2(3.5 \%) \\
0(0 \%) \\
1(1.8 \%)\end{array}$ & $\begin{array}{c}0.309 \\
\text { Neumonía } \\
\text { Insuf. resp. } \\
\text { Atelectasia } \\
\text { Distrés } \\
\text { Neumonía }\end{array}$ \\
\hline
\end{tabular}

NYHA: New York Heart Association.

\section{Discussion}

Medicine in general and surgery in particular have considerably evolved in recent years with the incorporation of less invasive diagnostic and therapeutic procedures, as, for example, with laparoscopic surgery systematically being used in the extraction of vesicles and/or interventions on the colon, owing to two fundamental reasons:

- Carrying out the procedures with less aggression and smaller surgical incision implies less postoperative pain, shorter hospital length of stay (with lower associated cost) and a faster return to patient usual life, including the labor area². 
- Aging of the population, with an increase in comorbidity, gives rise to an attempt to be as minimally invasive as possible in order to reduce surgical and postoperative risk.

- There is a third reason, not less important, that should not be forgotten, which is the patient desire for a more esthetic incision.

For all these reasons, and for the constant innovation in other surgical branches, heart surgery also tried to develop minimally invasive techniques since its inception. However, these techniques did not achieve the expected success, and generalization of this new trend was practically nonexistent. Currently, all this situation has turned around and, since a few years ago, a great revolution has occurred, which has driven minimal access cardiac surgery forward again, specially thanks to surgical steps standardization and generalization, showing that it is a technique with a necessary but rapidly assumable learning curve. With the purpose to analyze which are the results with the minimally invasive approach in our setting, specifically in our hospital, where it began to be systematically carried out since 2016, this study was devised, focusing on two items: patient intubation time with each technique and respiratory complications associated with each approach. Both items are highly relevant in cardiac surgery postoperative period, since they determine patients' ICU stay, occurrence of respiratory and other types of complications, need for ICU readmission and, in general, morbidity and mortality in the postoperative period. In the reviewed literature, the following results have been found with regard to these items:

- In the study by Filip et al., mean intubation time in the mini-sternotomy group was 8 hours, while in the sternotomy group it was 10 hours, with a statistically significant difference $(p=0.045)$ in favor of mini-sternotomy. However, in this study, no differences were found in terms of respiratory complications between both groups.

- In the study by Young et al., a difference of 2 hours was obtained for mean intubation time between both techniques, in favor of mini-sternotomy

- In the meta-analysis by Phan et al., a mean reduction of 4 hours in intubation time was observed in favor of the mini-sternotomy group.

These results were different from those in our study, since no statistically significant differences were found with regard to intubation time and respiratory complications between both groups as it was to be expected according to the consulted studies; moreover, the mini-sternotomy group experienced a larger number of respiratory events. This cannot be attributed to the fact that the groups were different and comprised more severely ill patients, since no statistically significant differences were obtained in the comorbidity variables analysis.

As for bleeding from the drains within the first 24 hours of the postoperative period, which is supposed to be lower with minimally invasive techniques by producing less aggression, it is a variable that has been difficult to assess in the literature, since most studies do not specify its quantity, but refer the need for transfusion, although the following has been found:

- In the study by Filip et al., mean output from the drains was $230 \mathrm{~mL}$ lower in the mini-sternotomy group with regard to the sternotomy group. However, they do not specify if they used pro-coagulant medication.

In our study, mean bleeding was lower in the mini-sternotomy group $(285.79 \mathrm{~mL})$, but the difference was not statistically significant.

One of the strong points in favor of mini-sternotomy, at least theoretically, is that it is related to a shorter ICU stay and shorter total hospital length of stay, as observed in the study by Phan et al., with a mean reduction in ICU stay of 0.6 days for the mini-sternotomy group. However, in our study, this difference could not be demonstrated and, moreover, it was in favor of the sternotomy group, with a mean ICU stay of 3.58 days vs. 5.65 days for the mini-sternotomy group $(p=0.004)$, while the sternotomy group had a mean hospital stay of 13.04 vs. 15.67 days in the mini-sternotomy group $(p=0.016)$. It is probable that these results in our study are due to the learning curve for the minimally invasive technique, both in the operating room and for patient management at the ICU, and to the fact that the first cases had a higher incidence of complications, which prolonged these patients' length of stay.

On the other hand, the mortality variable was superior, although slightly and without statistical significance, in the sternotomy group with regard to the mini-sternotomy group, specifically $5.3 \%$ vs. $1.8 \%$, which reflects that despite longer ICU and hospital stay and higher incidence of respiratory events, the mini-sternotomy group evolved more favorably than the sternotomy group. In the study by Paredes et al., mortality in the mini-sternotomy group was practically $0 \%$, while in the sternotomy group it was $5 \%{ }^{3}$.

Therefore, in our analysis, showing the presence of the advantages of minimally invasive surgery described by other studies has not been possible, especially in terms of mortality (as in the study by Paredes et al.), or 
in ICU stay and total hospital length of stay (as in the study by Phan et al.). Neither could a larger sample be obtained, as in the study by Cánovas et al., in which they recruited 963 patients undergoing aortic valve replacement mostly by mini-sternotomy, thanks to the collaboration of several centers, although the results of said study focused on minimal access techniques and did not compare them with the results of conventional technique, and thus establishing that minimal access cardiac surgery is a safe technique was possible, but not whether it is better, worse or the same as conventional surgery. Therefore, in our analysis, the main goal was to compare patient evolution with both techniques ${ }^{1,3}$.

\section{Conclusion}

In conclusion, demonstrating that minimal access surgery offers better results in comparison with the conventional technique was not possible in our analysis, probably due to the retrospective nature of the study, the sample size and, especially, the learning curve associated with the implementation of a new technique. If a prospective study comparing both techniques was currently to be devised in our department, after passing the learning curve, most likely we would obtain other, very different results demonstrating that minimal access surgery is a real alternative to conventional surgery and that, in a very near future, it will be the standard technique not only in the aortic valve.

\section{Funding}

This research has not received any specific grant from agencies of the public, commercial, or non-profit sectors.

\section{Conflicts of interest}

None.

\section{Ethical disclosures}

Protection of human and animal subjects. The authors declare that no experiments have been performed on humans or animals for this research.

Confidentiality of data. The authors declare that no patient data appear in this article.

Right to privacy and informed consent. The authors declare that no patient data appear in this article.

\section{References}

1. Paredes FA, Cánovas SJ, Gil Ó, García-Fuster R, Hornero F, Vázquez A, et al. Cirugía mínimamente invasiva para el recambio valvular aórtico. Una técnica segura y útil más allá de lo estético. Rev Española Cardiol. 2013;66(9):695-9.

2. Khoshbin E, Prayaga S, Kinsella J, Sutherland FW. Mini-sternotomy for aortic valve replacement reduces the length of stay in the cardiac intensive care unit: meta-analysis of randomised controlled trials. BMJ Open. 2011;1(2):e000266.

3. Rojas SV, Haverich A. Cirugía cardiaca mínimamente invasiva: ¿una alternativa segura para pacientes que requieren recambio valvular aórtico? Rev Esp Cardiol. 2013;66(9):685-6. 